\title{
Alien and native woody plants in scattered vegetation in agricultural landscape
}

\author{
Ján Supuka $^{1 *}$, Attila Tóth ${ }^{1}$, Mária Bihuňová ${ }^{1}$, Martina Verešová $^{1}$, Karol Šinka ${ }^{2}$ \\ ${ }^{1}$ Department of Garden and Landscape Architecture, Faculty of Horticulture and Landscape Engineering, \\ Slovak University of Agriculture in Nitra, Tr. A. Hlinku 2, \\ 94976 Nitra, Slovakia \\ ${ }^{2}$ Department of Landscape Planning and Land Consolidation, Faculty of Horticulture and Landscape \\ Engineering, Slovak University of Agriculture in Nitra, Tr. A. Hlinku 2, 94976 Nitra, Slovakia
}

\begin{abstract}
Supuka, J., Tóth, A., Bihuňová, M., Verešová, M., ŠınKa K., 2020. Alien and native woody plants in scattered vegetation in agricultural landscape. Folia Oecologica, 47 (2): 109-120.

The woody plant species composition has been evaluated in three cadastral territories of southwestern Slovakia, together in 77 habitats of non-forest woody vegetation (NFWV). A total of 43 tree species have been identified; 8 of them were alien and 5 species were cultural fruit trees. In total 20 shrub species were identified, out of which 3 were alien. Three woody species are classified as invasive according to the law in Slovakia: Acer negundo L., Ailanthus altissima (Mill.) Swingle, and Lycium barbarum L. They occurred only in 2, maximum in 4 of the evaluated habitats. The most occurring alien tree species Robinia pseudoacacia L. was generally identified in 58 habitats and in 48 habitats, with an incidence over $40 \%$ and dominance index of 70.6. The second most occurring alien tree Populus $\times$ canadensis had a dominance index of 8.3 . The dominant native trees in NFWV were Acer campestre L., Fraxinus excelsior L., Quercus robur L., Salix fragilis L. with the dominance index of 1-5 only.
\end{abstract}

\section{Key words}

agricultural landscape, southwestern Slovakia, species composition, woody plants

\section{Introduction}

In terms of biodiversity changes, the topic "biotic invasions" resonates in the scientific community from the beginning of the second half of the 20th century. It was presented in 1982 during the Scientific Committee on Environmental Problems (SCOPE) in the framework of the project "Ecology of Biological Invasions" (DrAKE et al., 1989). Biological invasion is characterised as the penetration, transfer, and introduction of species into areas and communities in which they did not naturally occur before and the subsequent expansion of these species (COLAUTTI and MaC IsAaC, 2004; Eliáš, 2009).
The introduction and transfer of woody plants to new areas have their historical background and reasons. The introduction advanced from phytogeographically and climatically comparable territories in mutual bilateral directions. Based on this principle, 9 gene centres have been defined with the assumption of plant introduction (SALAŠ and LuŽNÝ, 2010): 1) China (gene) centre, 2) Indian centre, 3) Central Asia, 4) Middle East, 5) Mediterranean centre, 6) Abyssinian centre, 7) South Mexico and Central America, 8) South America, 9) North America centre.

The reasons and objectives of plant introduction, including woody plants, are worldwide identical, as stated by several foreign authors (HENDERson, 1998; HeAD,

*Corresponding author: e-mail: jan.supuka@uniag.sk 
2017; PYŠEK et al., 2002; BURDA et al., 2015), or authors from Slovakia (BENČAŤ, 1982; MEDVECKÁ et al., 2012). The general reasons for introduction of woody plants can be defined as follows (BENČAŤ, 1982; SUPUKA, 1996, and others): a) enrichment of the species composition in food and forage sources; b) plants for the pharmaceutical and textile industry; c) woody plants for biomass production and for energy use; d) woody plants for forestry and wood industry; e) woody plants for changed environmental conditions and revitalisation of degraded land; f) range expansion of plants for social benefits; g) plants for research and breeding.

The process of plants introduction to and cultivation in new sites, can be specified into distinguished the following steps, which also represent the degree of success (BENČǍ̆, 1982): a) transfer, b) acclimatisation, c) adaptation, d) naturalisation, e) domestication.

Many introduced plants take invasive expression. They can eliminate former natural species and their biocoenoses (Elí́šs, 1997). The author describes 4 phases of the transfer process: introduction, colonisation, naturalisation, and spreading. The above cited author argues that out of 100 introduced species, only 2 to 3 can reach the free spreading phase with the invasion potential. Many authors describe the sources and causes of invasive behaviour of trees (plants) as a form of their life strategy (e.g. THÉBAUD and Debussche, 1991; Eliášs, 1997, 2009; Richardson et al., 2000; PYŠEK et al., 2002; WARREN, 2007; MEDVECKÁ et al., 2012; and others). Biological invasive assumptions include: big amount of seeds and diaspora, broad ecological adaptability, high allelopathic behaviour in succession, no or rare occurrence of diseases and pests, the way of seed spreading (mainly anemochores and hydrochores), root shoots and polycormone sprouting ability, neglected or incorrect management of invasive woody plant species (DraKe et al., 1989; Kelbel, 2012; HeAD, 2017).

The process of woody plant introduction is most often realised by botanical gardens and arboretums, where after a successful acclimatisation, these plants become a gene source for further research, reproduction and use in various social economy branches and in landscape creation (BENČAŤ, 1982; SUPUKA, 1996; KALOČAIOVÁ, 2005; HoŤKA and BARTA, 2012; KraJČOVIČOVÁ and ŠAJBIDOROVÁ, 2014; UHRIN et al., 2018).

Some of the introduced species in the naturalisation stage may form the theoretical potential for invasive growth or their invasive expansion has already been confirmed by research. In the Mlyňany Arboretum of the Slovak Academy of Sciences (SAS), 2,350 woody plant species have been identified, 40 species of them are considered as potentially invasive (based on ex situ seed selfproduction from an adult donor and self-regeneration) (KuBA and TomašKo, 2005. In the Botanical Garden of P. J. Šafárik University in Košice, 13 woody plant species with invasive and expansive reproduction and growth have been described (KelBel, 2005). Some alien woody species e.g. Acer negundo, Ailanthus altissima, Amorpha fruticosa, and Robinia pseudoacacia are resistant to the complex of abiotic and biotic factors (KeLBEL, 2012). These species are considered as invasive in Central European conditions by different authors and sources (RICHARDSON et al., 2000; PYŠEK et al., 2002; MODRANSKÝ and DANIŠ, 2006; MedvecKá et al., 2012; and others).

The introduction in woody plant species can have different invasive manifestations. Based on this theory, the following classification of invasive stages is presented (SUPUKA, 1997): a) invasive, b) protoexpansive, c) mesoexpansive, d) paraexpansive - often form mixtures with population of natural species, anthropogenically easy to control (e.g. Aesculus hippocastanum, Catalpa bignonioides, Elaeagnus angustifolia, Fraxinus americana). Another works (MoDRANSKÝ and DANIŠ, 2006; DANIš, 2008) present similar classification scheme where out of 104 assessed woody species, six species belonged to the group of invasive ones, 8 proexpansive, 20 mesoexpansive, 32 paraexpansive and 38 to the category of potentially expansive.

Within the 48 evaluated European countries, 5,789 alien plants have been mapped, 2,843 of them were introduced from outside of Europe. In terms of occurrence, $64.1 \%$ of alien plants occur in the urban-industrial landscape and $58.5 \%$ in the agricultural landscape, parks, and gardens. The category of ornamental and horticultural introduction includes $52.2 \%$ of introduced plants (LAMBDON et al., 2008). The Czech alien flora consists of 1,454 species, 350 of them are archaeophytes and 1,104 are neophytes. According to the invasive status of the total number of species, 985 are classified as casuals, 408 as naturalised but not invasive, and 61 as invasive (PYŠEK et al., 2012). The Slovak allochthonous flora consists of 916 introduced plants, 282 of them are plant species in the category of archaeophytes and 634 neophytes. According to their invasion status, most introduced species are casual - 507 species, followed by naturalised, but not invasive -344 and invasive - only 29 species (MEDVECKÁ et al., 2012).

Under the Act No. 158/2014 Coll. and the Act No. $356 / 2019$ Coll. on Nature and Landscape Protection in Slovakia, 7 herb species and 4 woody plant species were included in the category of invasive plants: Acer negundo, Ailanthus altissima, Amorpha fruticosa, Lycium barbarum, (https://www.enviro.gov.sk).

In the agricultural landscape, introduced woody plants were planted as fruit species, or into spatial compositions of scattered non-forest woody vegetation (NFWV) for the purpose of multiple benefits. They were disseminated from the originally planted sites to adjacent areas by humans or by other vectors (wind, water, birds, and animals etc.). According to many studies conducted in European countries (RICHARDSON et al., 2000; LAMBDON et al., 2008; PYŠEK et al., 2012; MEDVECKÁ et al., 2012.; ŠPUlEROvá et al., 2017; BuRDA, 2018), alien woody plant species were found in various habitats in agricultural landscape such as: fields, grasslands, forest-steppes, synanthropic wastelands, windbreaks and groves, small woodlands, shrublands, road sites, river banks, wetlands and marshes, traditional vineyards and orchards. In the agricultural landscape of Ukraine, beside native and alien herbal species, 11 woody species were mapped also, e.g. Acer negundo, Ailanthus altissima, Amorpha fruticosa, Celtis occidentalis, Juglans cinerea, (BuRDA, 2018). In scattered NFWV of the agri- 
cultural landscape of Bohemia, in regions of Nové Dvory and Žehušice, a significant occurrence of alien woody species such as Acer negundo, Robinia pseudoacacia, Syringa vulgaris, and Symphoricarpos albus have been indicated (DEMKOví and LIPSKÝ, 2012).

This paper aims to contribute to the existing knowledge of alien and invasive woody plants in scattered vegetation in agricultural landscape through 4 specific goals: (1) to evaluate the woody plant composition in spatial habitats of non-forest woody vegetation in three chosen cadastral areas in the agricultural landscape of Slovakia, (2) to classify tree species according to their origin and degree of invasive spreading, (3) to evaluate the habitats according to structural characteristics, such as frequency and dominance of woody plants with emphasis to alien and invasive species, (4) to describe the woody plant species presence in terms of biodiversity and the potential for invasion into surrounding landscape.

\section{Materials and methods}

\section{Site characteristics}

Research of woody plant species with emphasis on the differentiation of native and alien species was carried out in various spatial habitats of non-forest woody vegetation (NFWV) in agricultural landscape. For this purpose, three cadastral territories in southwestern Slovakia were chosen: Horné Lefantovce (HL, 40 NFWV were assessed), Čajkov (C, 24 NFWV were assessed) and Dunajský Klátov (DK, 13 NFWV were assessed). The studied areas had comparatively different phytogeographical characteristics, which are also reflected in the composition of the evaluated woody plant species.

\section{Horné Lefantovce cadastral territory}

The area belongs to the geographical unit of the Western Carpathians in the northwest part of the mountain range Tribeč, including the mountain complexes Zobor and Žibrica. The cadastral territory is situated at the foot of the Tribeč hills forming its eastern border and the floodplain valley of the Nitra river, forming the western border of the territory. The potential natural vegetation consists of oakhornbeam Carpathian forests, and at higher altitudes also oak-beech forests (MAGLOCKÝ, 2002). Hard floodplain forests were identified in the Nitra river valley on the western edge of the territory. The cadastral territory covers an area of 1,867.7 hectares and reaches a range of 194-458.5 m asl. In terms of land use, the following landscape elements are present: forests $54.4 \%$, agricultural landscape $35.5 \%$, built-up area $2.7 \%$ (SUPUKA et al., 2013).

\section{Čajkov cadastral territory}

The area is located on the southern slopes of the western part of the Štiavnické Mountains. The northern boundary is formed by the ridge of this mountain range, the southern boundary of the cadastre is formed by the edge of the Danube Upland. From phytogeographical point of view, forest-steppe communities and oak-hornbeam Carpathian forests dominate (MAGLOCKÝ, 2002). The cadastral territory has an area of 2,394.5 hectares with an altitude ranging from 190 to $747 \mathrm{~m}$ asl. In terms of land use, the following landscape elements are represented: forests $55.5 \%$, agricultural landscape $38.8 \%$, built-up area $2.4 \%$. The territory has a rich wine-growing tradition, where the present area is 138 hectares. Up to $70 \%$ of the area belongs to historical mosaic structures, where there is also a rich occurrence of exotic trees with a predominance of rare fruit species (VEREŠOvá and SuPUKA, 2012).

\section{Dunajský Klátov cadastral territory}

The assessed area belongs to the geographical unit of the Danubian Lowland, part of the Danubian Plain with fluvial to oeolian-fluvial natural landscape. The altitude ranges from 110.5 to $118.9 \mathrm{~m}$ asl. The potential natural vegetation is represented by willow-poplar and ash-elmoak forests (MAGLOckÝ, 2002). The assessed area with a unit name forms a landscape segment with a total area of 1,968.1 hectares, and 7 cadastral areas: Malé Blahovo, Malé Dvorníky and Vel'ké Dvorníky, Dunajský Klátov, Jahodná, Ohrady, Vydrany, This segment was chosen owing to the occurrence of non-forest woody vegetation, where native and alien species were evaluated. From the land-use point of view, the dominant part is agricultural landscape $83.6 \%$ (90\% of agricultural landscape is arable land), $6.6 \%$ is covered by forests, and $2.8 \%$ by built-up areas (SUPUKA and ŠINKA, 2018).

\section{Research methods and woody plant assessment}

The woody plant species were mapped and evaluated in terms of their origin and potential of invasive spreading, respectively; according to a modified original methodology of expansion assessment (SuPUKA, 1997). The following categorisation was used in this paper:

Aa) Invasive woody plant species: produce large amounts of diaspores (seeds), spread by wind, water and animals over 50 to $100 \mathrm{~m}$ from donor, high seed survival, strong generative and vegetative self-reproduction, including bud shoots. They have a high allelopathic and competitive ability, inhibit the growth and displace populations of other native but also many introduced species. They often create monocultures. Mechanical and chemical control is difficult and ineffective. Coexistence with ecologically related species is possible, rarely in the population core, more frequent at the margins. The following species have been included in this group: Acer negundo, Ailanthus altissima, Lycium barbarum, Robinia pseudoacacia; or, alien herbs Impatiens sp., Reynoutria sp.

$\mathrm{Ab})$ Protoexpansive woody plant species: produce a lot of diaspores, show a relatively strong self-reproducing ability from seeds or root polycormones. They have moderate competitive abilities against other species, often forming compact group populations within close reach of the parent (up to 20 to $40 \mathrm{~m}$ ). This group includes for example: Amorpha fruticosa, Catalpa bignonioides, Celtis occidentalis, Paulownia tomentosa, Pyracantha coccinea, Rhus typhina, Syringa vulgaris.

Ac) Mesoexpansive woody plant species: create sev- 
eral seeds of various types. They show good self-reproducing ability from seeds and root rejuvenates. They create autonomous, often dense group populations. They have a weaker competitive ability, often growing in coexistence with other species. This group includes: Berberis aquifolium, Campsis radicans, Elaeagnus angustifolia, Hippophae rhamnoides, Fraxinus americana, Laurocerasus officinalis, Parthenocissus quinquefolia, Populus $\times$ canadensis, Rosa rugosa.

Ad) Paraexpansive woody plant species produce many and often large fruits that are barochorous or zoochorous. They are naturalised and domesticated, many of them have a good fruitiness and good self-reproducing ability. Coexistence with other species is common and realistic. This group includes: Aesculus hippocastanum, Juglans nigra, J. regia, Morus alba, Prunus amygdalus, P. cerasifera, Quercus rubra.

The field survey of woody plants in spatial categories of NFWV was performed in three cadastral territories: Čajkov (C) - in 2012, Horné Lefantovce (HL) - in 2013, Dunajský Klátov (DK) - in 2015. In each category of NFWV, woody plant species were evaluated separately in the tree layer and in the shrub layer. Here, we separately evaluated the coverage of the tree and shrub layer and the abundance of individual tree and shrub species in layers, with an accuracy of 5\%. (SUPUKA et al., 2013).

Frequency of woody plant occurrence in NFWV was specified to four groups:

* - dominant and very often occurrence, over $40 \%$

$\mathrm{X}$ - occurrence in 10 to $40 \%$

+- occurrence less than $10 \%$

0 - no occurrence.

Woody species were evaluated according to their origin (A - alien, $\mathrm{N}$ - native) and according two spatial categories of habitats (A, B) and their composition types $(1,2,3)$ (SupuKa et al., 2013):

A) Area or group habitat of woody plants, or NFWV

1 - Solitary tree

2 - Small forests, groves, extensive and abandoned orchards

3 - Forests and groups in contact areas of water bodies

B) Linear habitat of woody plants, or NFWV

1- Windbreaks and forest protection belts with antierosion function, woody lines at the border of plots

2 - Roadside vegetation and vegetation along railways

3 - Riverside vegetation, vegetation along water streams and canals. Methods of structural traits assessment of the habitats
and their statistical evaluation

Based on field records and evaluation of individual woody plant species frequency, structural traits of evaluated habitats (respectively elements of NFWV) were assessed (JuRKo, 1990; MoraVEC et al., 1994; SupuKa et al., 2013): a) Dominance index of alien woody species for each cadastral territory. Alien species are considered dominant if they occur in the evaluated NFWV (habitats) to an extent higher than $40 \%$. The dominance index and frequency index were calculated for native and alien tree species with an incidence above $10 \%$, also with an incidence above $40 \%$ coverage. The dominance and frequency of shrubs existence was considered according to incidence above $5 \%$ of coverage.

$$
D i(x)=\sum_{i=1}^{n} \frac{N d}{N} \times 100,
$$

where $D i$ is dominance index of woody plant species, $N d$ is significance value of the $\mathrm{i}$-the alien tree species, and $N$ is sum of significance values of all species with defined occurrence.

$$
N d=P A \times F,
$$

where $N d$ is species significance coefficient, $P A$ is the average area cover of the species in assessed NFWV habitats where the species occurred, $F$ is number of NFWV habitats in which the species occurred within a defined cover (species stability).

b) Frequency index of woody species occurrence

$$
F=\frac{P d}{P c} \times 100
$$

where $P d$ is number of habitats in which the woody species occurred, and $P c$ is total number of habitats in the evaluated territory.

For the purpose of statistical evaluation of the habitat traits, we used the non-metric multidimensional scaling (NMDS) and Bray-Curtis index for analyses of similarities between studied cadastral territories and the frequency of occurrence of individual tree species in assessed habitats. Bray-Curtis index expresses a quantification of woody species on different studied cadastral territories. The statistical analysis was done using the statistical software PAST (HAMMER, 2015).

\section{Results}

The paper is focused on the analysis of woody species composition in spatial habitats of non-forest woody vegetation (NFWV) in the agricultural landscape in three different cadastral territories: Horné Lefantovce (HL), Čajkov (C), and Dunajský Klátov (DK). As presented in the methodology, the studied areas have different phytogeographical features, different natural and fertility potential, but almost identical history development and changes in landscape structure. Changes in agricultural land use are caused due to land ownership, intensification of agriculture technologies and management processes. A turning point in this matter was the collectivisation and industrialisation of agriculture in the 1950s in Slovakia. The dominant impacts were from the land consolidation, with progressive arable land formation into large blocks (often exceeding 100 hectares or more, mainly in lowlands), chemical substances supplemented for plant nutrition and plant protection purposes. As a result, the landscape structure has changed, the ecological stability of the landscape and the 
environmental quality of soil, water and air decreased. This process took place in almost all developed countries, but in the form of the natural market consolidation and intensification. Based on the results of international scientific research, to mitigate the negative phenomenon of intensified agricultural management, there were elaborated the theoretical base and practical advices for applying (implementation) of forest fragments into the agricultural landscape. These fragments have the character of groups or lines. The terminology may be different, but the substance is identical, e.g. protective forest belts, windbreaks, non-forest woody vegetation, fragmented forest habitats (SuPUKA and ŠINKA, 2018). The integration of these components into the agricultural landscape took place in former Czechoslovakia (ZACHAR and TEŠLIAR, 1989; DEMKOVÁ and LIPSKÝ, 2012; SUPUKA et al., 2013). Planting mainly NFWV line habitats in Slovakia was carried out in 1950s and 1960s, including the agricultural landscape of the evaluated cadastral territories. In this process, there were used also alien woody plants, some of them recently classified as 'invasive'. During the years 2012-2015, 77 habitat formations of NFWV were evaluated in three cadastral territories, and their woody species composition were assessed. The base elements in the NFWV habitats are tree species, shrub species are at the margins or in the undergrowth. We have identified 43 tree species, 8 of them were alien and 5 were cultural fruit species (e.g. cherries, plums, pears). This group is represented by both allochthonous and autochthonous species. Many introduced woody plants are already domesticated as important fruit species belonging to the group of archaeophytes (e.g. Juglans regia, Prunus amygdalus). It has been shown that the proportion of alien species is not so high compared to the native species. Acer campestre, Fraxinus angustifolia, $F$. excelsior, Populus alba, P. nigra, Prunus padus, Quercus robur, Salix alba, S. fragilis and Ulmus laevis are the most common native tree species found in the studied habitats. These species are typical representatives of softwood and hardwood floodplains and they were found in habitats along water streams, canals, the watersides of ponds, fragments of wetlands in the cadastral territory of Dunajský Klátov. On drier localities and slopes in the other two cadastral territories (Horné Lefantovce, Čajkov), the most abundant native species were represented by the genus Acer, Quercus (mainly Q. cerris, Q. petraea), Fraxinus excelsior, species of the genus Malus, Prunus, Pyrus, and Tilia. The introduced alien tree species were represented by Acer negundo, Acer saccharinum, Aesculus hippocastanum, Ailanthus altissima, Celtis occidentalis, Populus $\times$ canadensis, Prunus cerasifera, Robinia pseudoacacia (Table 1). These are predominantly found in planted windbreaks, protective belts, and tree alleys along roads or as planted monocultures (Populus $\times$ canadensis, Robinia pseudoacacia). The core tree in windbreaks in all three cadastral territories was clearly Robinia pseudoacacia, occurring in 58 of all 77 examined habitats (Table 1). This species is dominant in windbreaks and protective belts in the cadastral area of Horné Lefantovce, the lowest presence was found in the cadastral area of Dunajský Klátov, with a higher representation and dominance of the culti- vated hybrid species Populus $\times$ canadensis. According to the methodology, we processed the occurrence of tree species occurring in the proportion above $10 \%$ in the assessed habitats, by cadastral territories. At the same time, we calculated the structural features of habitats in terms of the dominance and frequency of tree species (Table 2). The diversity of woody species was almost the same, 14-16 species in each evaluated cadastral territory. The differences were only in the representation of species, which also reflected the ecological conditions of the evaluated areas. There were 4 to 5 alien species in each territory. The sporadic occurrence includes Acer saccharinum (roadside alley in Čajkov cadaster), Aesculus hippocastanum (often in tree alleys along roads), Ailanthus altissima (only in windbreaks in Dunajský Klátov cadaster), Acer negundo (Čajkov and Dunajský Klátov only). The structural character of habitats was also evaluated with the occurrence of tree species above $40 \%$ in all studied areas together, with an emphasis on significant dominance (Table 3). Dominant in windbreaks was Robinia pseudoacacia in the order from the highest to lowest frequency, but also in relation to the cadastral territory (Horné Lefantovce - most frequent, Čajkov - less frequent, Dunajský Klátov - least frequent). Black locust in up to 48 habitats had an incidence of over $40 \%$ with a dominance index of 70.6 and most often formed monocultures in the assessed windbreaks. Populus $\times$ canadensis, which had the highest frequency in the cadastral area of Dunajský Klátov and the lowest in Horné Lefantovce, was second in dominance. Wind, water, and animals are the basic vectors of alien species diaspore spread. The most pronounced manifestation of expansion was found in Acer negundo, Ailanthus altissima, Robinia pseudoacacia. Lower manifestation of self-reproduction and survival of new individuals was found in Celtis occidentalis, Fraxinus americana, Prunus cerasifera, but also in the domesticated fruit species Juglans regia. In summary, the process of self-reproduction and dissemination has been identified in all alien tree species except for Aesculus hippocastanum and Populus $\times$ canadensis.

In the field work, we have paid attention also to the occurrence of shrub species in habitats of NFWV according to the surveyed cadastral territories (Table 4). A total of 20 shrub species have been identified, 3 of them were alien. Every habitat in the evaluated cadastral territory had 11 to 14 species of shrubs, most of them were in Dunajský Klátov. Shrubs were identified at the edges of NFWV habitats (as a category of ecotones) or as undergrowth of trees. A very common undergrowth of Robinia pseudoacacia was formed by Sambucus nigra. Mainly in the sloping areas of the Horné Lefantovce and Čajkov cadastral territories, line habitats (hedges) of shrubs or with sporadic occurrence of trees were identified. They are the remains of former boundaries, terrain balks and terraces or land boundaries. Shrubs provide very important ecosystem services in NFWV habitats in the agricultural landscape. Their presence enhances the biodiversity, they are a part of the food chain or they provide shelters for different wildlife species (e.g. animals, birds, insects), they increase protective effect of line form habitats, ecological stability, as well as visual and aesthetic landscape values. 


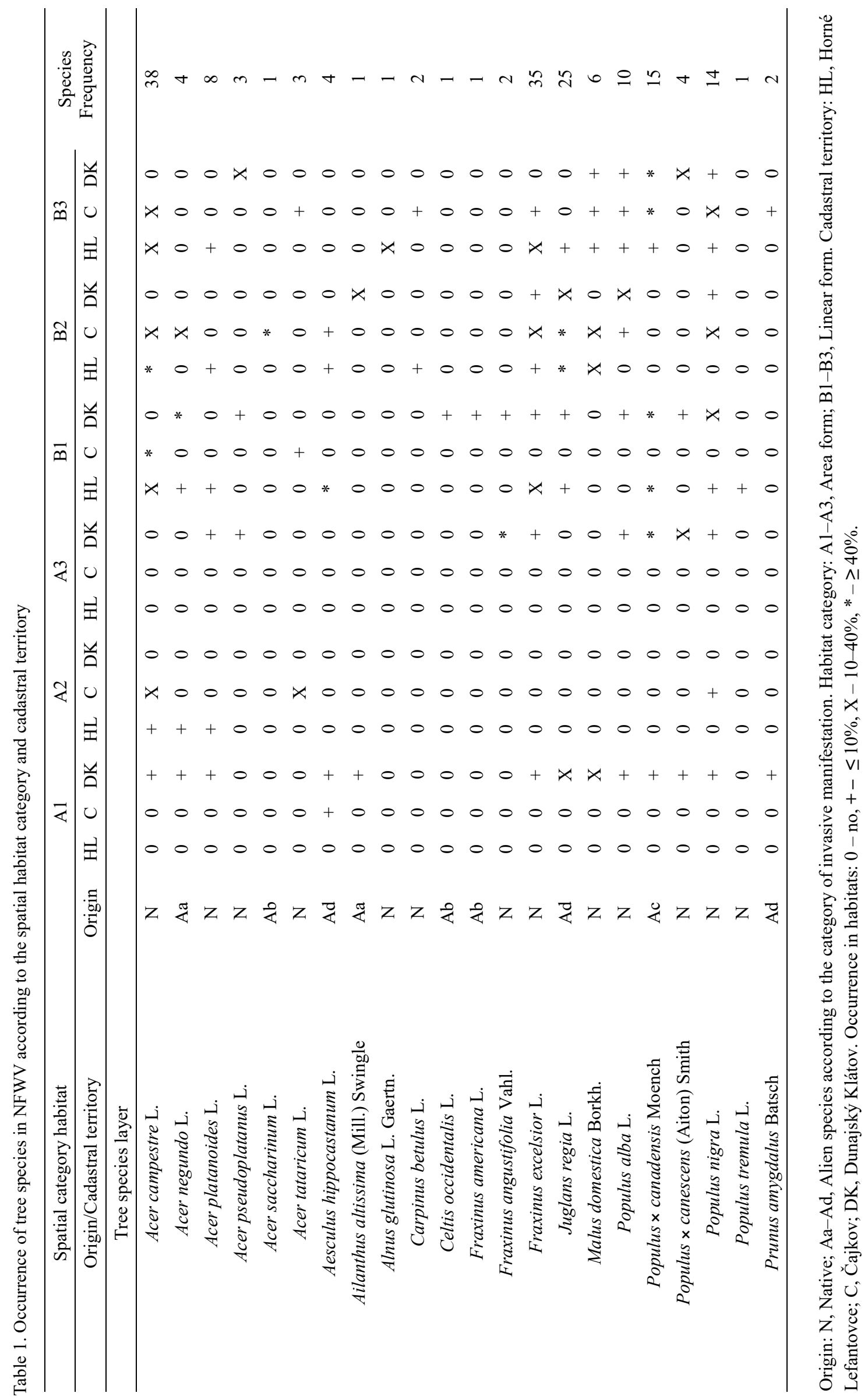




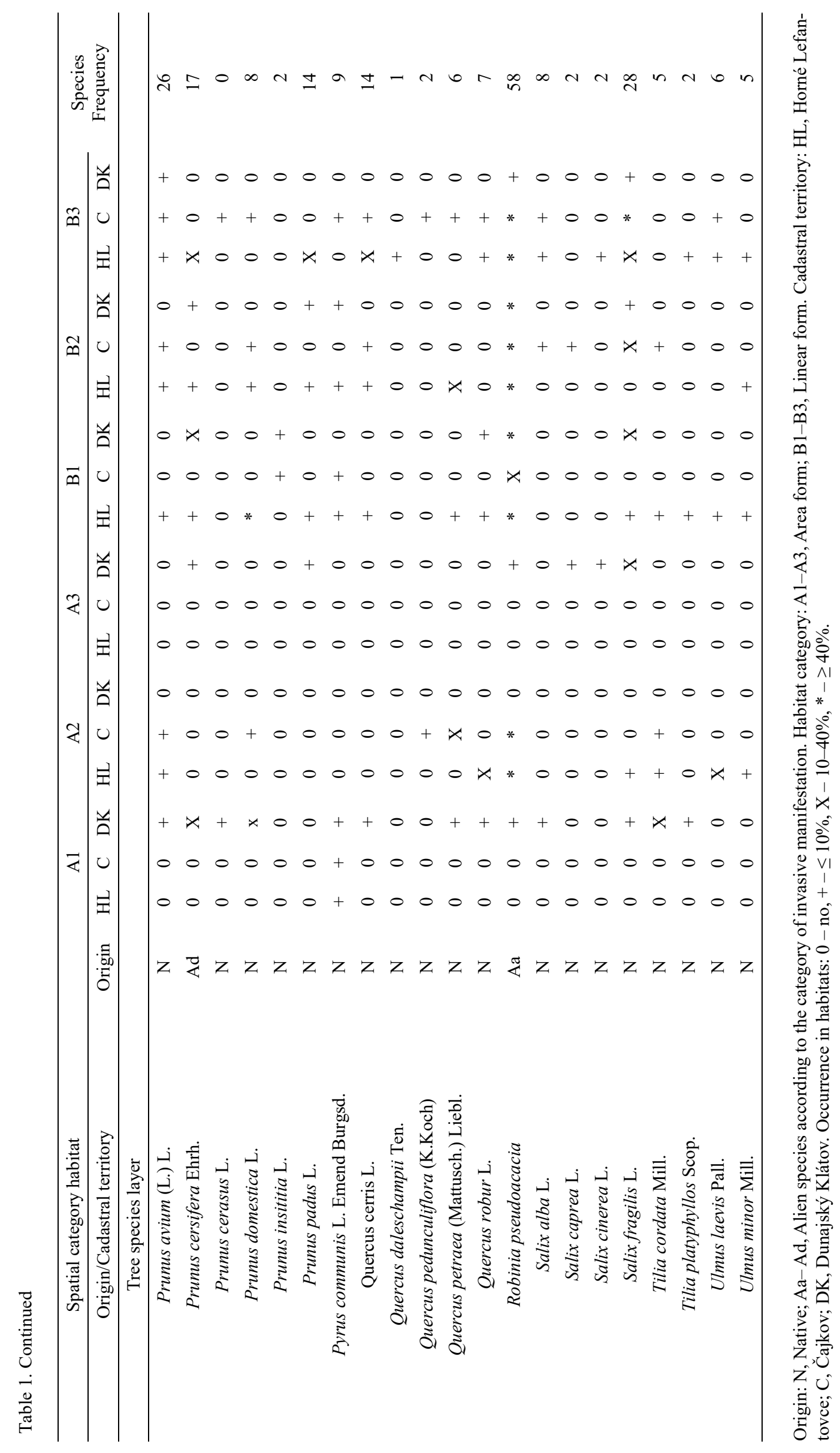


Table 2. List of tree species manifesting beyond $10 \%$ occurrence in the studied cadastral territories, with their dominance and frequency

\begin{tabular}{|c|c|c|c|c|c|c|}
\hline \multirow{2}{*}{$\begin{array}{c}\text { Cadastral territory } \\
\text { Tree species }\end{array}$} & \multicolumn{2}{|c|}{ Horné Lefantovce (HL) } & \multicolumn{2}{|c|}{ Čajkov (C) } & \multicolumn{2}{|c|}{ Dunajský Klátov (DK) } \\
\hline & Dominance & Frequency & Dominance & Frequency & Dominance & Frequency \\
\hline Acer campestre & 10.0 & 60.0 & 12.20 & 58.3 & - & - \\
\hline Acer negundo & 0.0 & 0.0 & 0.90 & 4.1 & 3.60 & 15.4 \\
\hline Acer pseudoplatanus & - & - & - & - & 1.80 & 23.1 \\
\hline Acer saccharinum & - & - & 4.60 & 4.2 & - & - \\
\hline Acer tataricum & - & - & 0.60 & 12.5 & - & - \\
\hline $\begin{array}{c}\text { Aesculus } \\
\text { hippocastanum }\end{array}$ & 1.1 & 5.0 & - & - & - & - \\
\hline Ailanthus altissima & - & - & - & - & 2.80 & 7.7 \\
\hline Alnus glutnosa & 0.8 & 2.5 & - & - & - & - \\
\hline $\begin{array}{l}\text { Fraxinus } \\
\text { angustifolia }\end{array}$ & - & - & - & - & 6.40 & 15.4 \\
\hline Fraxinus excelsior & 6.4 & 50.0 & 0.60 & 33.3 & 4.60 & 53.8 \\
\hline Juglans regia & 3.3 & 30.0 & 8.50 & 29.2 & 5.50 & 46.1 \\
\hline Malus domestica & 1.3 & 5.0 & 4.90 & 12.5 & - & - \\
\hline Populus alba & - & - & 0.60 & 12.5 & 5.00 & 46.1 \\
\hline $\begin{array}{l}\text { Populus } \times \\
\text { canadensis } \\
\text { Populus } \times\end{array}$ & 2.8 & 7.5 & 8.80 & 16.6 & 21.90 & 61.5 \\
\hline canescens & - & - & - & - & 4.60 & 23.1 \\
\hline Populus nigra & - & - & 2.50 & 16.6 & 8.70 & 69.2 \\
\hline Prunus cerasifera & 2.5 & 22.5 & - & - & 5.00 & 61.5 \\
\hline Prunus domestica & 1.4 & 10.0 & 1.20 & 16.7 & - & - \\
\hline Prunus padus & 2.7 & 27.5 & - & - & 1.80 & 23.1 \\
\hline Quercus cerris & 1.1 & 25.0 & - & - & - & - \\
\hline Quercus petraea & 0.3 & 7.5 & 1.20 & 12.5 & - & - \\
\hline Quercus robur & 0.9 & 10.0 & - & - & - & - \\
\hline $\begin{array}{c}\text { Robinia } \\
\text { pseudoacacia }\end{array}$ & 61.2 & 85.0 & 41.20 & 58.3 & 17.40 & 76.9 \\
\hline Salix fragilis & 2.5 & 17.5 & 12.20 & 45.8 & 10.90 & 76.9 \\
\hline Tilia cordata & - & - & - & - & - & - \\
\hline Ulmus laevis & 1.7 & 10.0 & - & - & - & - \\
\hline Total & 100.00 & & 100.00 & & 100.00 & \\
\hline $\begin{array}{c}\mathrm{N}-\text { Summary } \\
\text { occurrence }\end{array}$ & 3,195 & & 1,565 & & 1,095 & \\
\hline
\end{tabular}

The spring blossom of native Prunus spinosa and Rosa canina show the largest dominance and frequency occurrence in habitats. Other important evaluated native plants are species of genera Cornus, Crataegus, Euonymus, Ligustrum, Rhamnus, Rubus, and Sambucus (Table 4). There were identified only 3 alien shrub species, mainly in habitats of contact zones between the human settlements and open landscapes. Syringa vulgaris is considered to have been planted intentionally, then, it consequently expanded by root polycormones. The other two species are disseminated by birds (Lycium barbarum, Parthenocissus tricuspidata) or polycormones (Lycium barbarum). The frequency and dominance of alien shrubs in the studied NFWV habitats are very low and we do not expect any significant invasive pressure on natural woody communities. The self-reproductive process and succession of new young individuals have been identified in habitats, but they were not spontaneous and with no high frequency.

Windbreaks planted on arable land in linear forms are maintained and controlled indirectly - by ploughing to the edge of the windbreaks, eliminating new seedlings and root shoots. On enclaves and gaps, on unkempt grasslands at the edges, or inside habitats, the process of self-reproduction of alien trees and shrubs and filling these gaps was evident, especially with the most expansive woody species mentioned above.

The differences in the frequency of occurrence of individual tree species between the assessed cadastral territories are shown with the results of non-metric multidimensional scaling (NMDS) analysis and based on Bray-Curtis similarity measures (Fig. 1). The stress value is 0.1024 , which indicates a medium quality of the model. Some of 
Table 3. Dominance and frequency of tree species with more than $40 \%$ occurrence in the studied habitats at all cadastral territories

\begin{tabular}{ccc}
\hline \multirow{2}{*}{ Tree species } & \multicolumn{2}{c}{$\begin{array}{c}\text { cadastral territories } \\
\text { (HL, C, DK) }\end{array}$} \\
\cline { 2 - 3 } & Dominance & Frequency \\
\hline Acer campestre & 5.0 & 3.9 \\
Acer negundo & 1.1 & 1.3 \\
Acer saccharinum & 2.1 & 1.3 \\
Aesculus & 1.1 & 1.3 \\
hippocastanum & & 1.3 \\
Fraxinus & 1.6 & 5.2 \\
angustifolia & 7.6 & 5.2 \\
Juglans regia & 8.3 & 1.3 \\
Populus $\times$ & 1.3 & 48.1 \\
canadensis & 70.6 & 1.3 \\
Prunus domestica & 1.3 & \\
Robinia & 100.00 & \\
pseudoacacia & & \\
Salix fragilis & & \\
Total & &
\end{tabular}

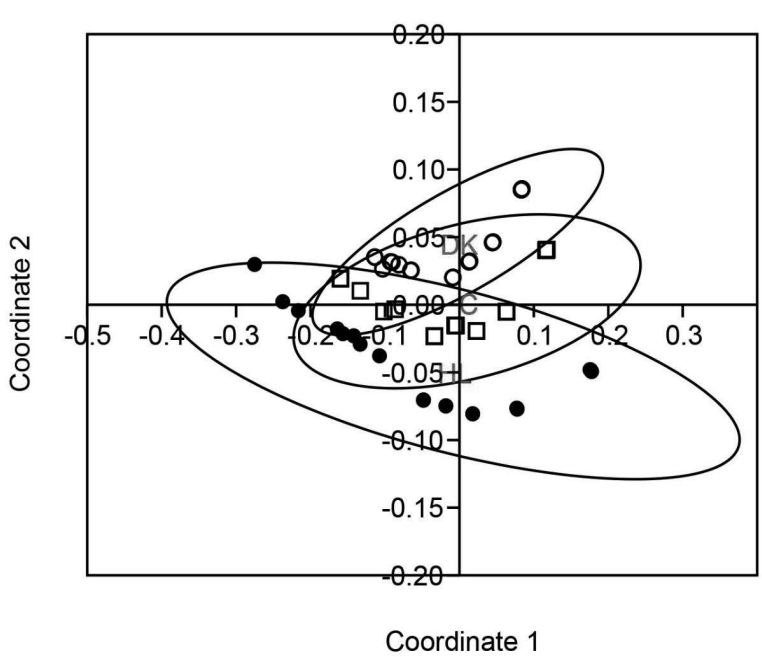

Fig. 1. Non-metric multidimensional scaling ordination of sites based on Bray-Curtis similarity measures representing the tree species occurrence in the studied cadastral territories. Horné Lefantovce (full dots), Čajkov (open squares) and Dunajský Klátov (open dots). Stress $=0.1024$.

Table 4. Dominance and frequency of shrub species with more than $5 \%$ occurrence in the studied habitats according to the cadastral territories and total cadastral territories (Total)

\begin{tabular}{|c|c|c|c|c|c|c|c|c|}
\hline \multirow{2}{*}{$\begin{array}{c}\text { Cadastral territory } \\
\text { Shrub species }\end{array}$} & \multicolumn{2}{|c|}{ Horné Lefantovce } & \multicolumn{2}{|c|}{ Čajkov } & \multicolumn{2}{|c|}{ Dunajský Klátov } & \multicolumn{2}{|c|}{ Total } \\
\hline & Domin. & Freq. & Domin. & Freq. & Domin. & Freq. & Domin. & Freq. \\
\hline Clematis vitalba $\mathrm{L}$. & 2.7 & 30.0 & 0.2 & 4.1 & - & - & 1.0 & 16.9 \\
\hline Cornus mas L. & 0.3 & 5.0 & 0.2 & 4.1 & - & - & 0.2 & 3.9 \\
\hline Cornus sanguinea L. & 0.3 & 5.0 & 4.4 & 41.7 & 20.1 & 76.9 & 0.1 & 28.6 \\
\hline Corylus avellana $\mathrm{L}$. & - & - & 0.2 & - & - & - & 0.1 & 2.6 \\
\hline $\begin{array}{l}\text { Crataegus laevigata } \\
\text { (Poir.) DC }\end{array}$ & 9.0 & 42.5 & 8.8 & 41.6 & 12.1 & 69.2 & 10.0 & 46.7 \\
\hline $\begin{array}{c}\text { Crataegus monogyna } \\
\text { Jacq. }\end{array}$ & 9.8 & 40.0 & 7.9 & 50.0 & 7.6 & 61.5 & 8.4 & 46.7 \\
\hline Euonymus europaeus L. & 5.3 & 47.5 & 1.8 & 25.0 & 2.8 & 46.1 & 3.3 & 40.3 \\
\hline Frangula alnus Mill. & - & & - & & 5.5 & 61.5 & 1.8 & 10.4 \\
\hline Ligustrum vulgare L. & 2.8 & 37.5 & 0.2 & 4.2 & 1.0 & 23.0 & 1.3 & 24.7 \\
\hline Lycium barbarum L. & 0.2 & 2.5 & - & - & - & - & 0.1 & 1.3 \\
\hline $\begin{array}{c}\text { Parthenocissus } \\
\text { quinquefolia (L.) Planch. }\end{array}$ & 0.2 & 2.5 & - & - & - & - & 0.1 & 1.3 \\
\hline Prunus insititia L. & - & - & - & - & 2.4 & 46.1 & 0.8 & 7.8 \\
\hline Prunus spinosa L. & 25.1 & 90.0 & 37.3 & 95.8 & 7.9 & 53.8 & 23.4 & 85.7 \\
\hline Rhamnus cathartica L. & 1.0 & 12.5 & - & - & 6.2 & 69.2 & 2.4 & 18.2 \\
\hline Rosa canina $\mathrm{L}$. & 21.4 & 92.5 & 24.1 & 83.3 & 5.5 & 69.2 & 17.0 & 85.7 \\
\hline Rubus fruticosus $\mathrm{L}$. & 5.8 & 47.5 & 9.4 & 37.5 & 5.9 & 76.9 & 7.0 & 49.3 \\
\hline Salix viminalis & - & & - & & 0.3 & 7.6 & 0.1 & 1.3 \\
\hline Sambucus nigra L. & 15.4 & 67.5 & 5.5 & 54.1 & 22.1 & 92.3 & 22.5 & 67.5 \\
\hline Syringa vulgaris L. & 0.5 & 5.0 & - & - & - & - & 0.2 & 2.6 \\
\hline Viburnum opulus L. & - & - & - & - & 0.7 & 15.3 & 0.2 & 2.6 \\
\hline Total & 100.0 & & 100.0 & & 100.0 & & 100.0 & \\
\hline $\mathrm{N}$ - Summary occurrence & 3,010 & & 2,265 & & 1,450 & & & \\
\hline
\end{tabular}


the counting points within the three assessed cadastral areas are overlapping, which indicates the similarity of tree species occurrence mainly in Dunajský Klátov and Čajkov cadastral territories. The cadastral territory area of Horné Lefantovce shows higher difference in tree species occurrence compared to the other two cadastral areas assessed.

\section{Discussion}

The planting of alien trees in small woodlands and scattered NFWV in agricultural landscape is historically linked to the intensification and industrialisation of agriculture and the rapid increase in the shares of arable land in largescale plots. One of the most comprehensive documents on the subject is the proceedings of scientific papers from the 3rd International conference in Canada 'Windbreaks and agroforestry' (FINCH and BALDWIN, 1991). Altogether 87 scientific papers present problems and ways of solution in more than 15 countries of the world, e.g. Canada, Australia, Russia, China, France, UK, India, Egypt, Argentina, and Czechoslovakia. All mentioned published articles and other sources (SOLTNER, 1991) deal with planting of native and alien woody plants in composed elements of NFWV. Windbreaks with a total length of $30 \mathrm{~km}$ were planted in the Danube Lowland of Slovakia between 1951 and 1955 (ZACHAR and TEŠLIAR, 1989), where in 19 currently assessed windbreaks there were identified 27 tree species, including 10 alien with 3 invasive species (SUPUKA and ŠINKA, 2018). From the published sources, we have found that Europe was particularly attractive to American tree species, with Robinia pseudoacacia significantly dominating the habitats of NFWV in agricultural landscapes. For instance, TótH et al. (2016) have mapped and assessed three selected cadastral territories in the Nitra Region and derived a conclusion that Robinia pseudoacacia has the highest frequency factor among all identified predominant tree species in NFWV structures. In the European List of Invasive Plants, up to 7 woody plant species are in the category of invasive (BRUNDU and RICHARDSON, 2016). We have identified 3 invasive tree species in our studied areas. Black locust is almost accepted in Europe as far as a domesticated alien tree, due to its historical services and benefits, e.g. timber biomass, melliferous effect and better adaptability to changed environment in comparison to the native species (BENČǍ, 1982). When assessing woody plant species in suburban and rural landscape in individual NFWVs (Hodge, 1995), there were also used the structural features of habitats such as species frequency, mean density of plots, woody plant high stratum and importance value (WHITE et al., 2014). We applied similar structural features of habitats, such as frequency and dominance of woody plant species and their percentage coverage in evaluated NFWV elements. In our study, we identified an indirect control of invasive tree species in windbreaks by annual ploughing along the windbreak boundaries. In Hungary, there are applied more methods for controlling and eliminating black locust (Robinia pseudoacacia) and tree of heaven (Ailanthus altisima), e.g. chemicals, sprout cutting, or removing bark from tree trunks (KoRDA, 2015). It is necessary to give emphasis on woody plants that in many European and Slovak documents (EU Regulation No. 2019/1262, Regulation of the Government of the Slovak Republic No. 449/2019 Coll. and, the Act on Nature and Landscape Protection No. 543/2002 Coll. as amended by $356 / 2019$ and others) are listed an invasive plant species that raise concerns about possible disturbances in natural ecosystems (https://www.enviro.gov.sk). In the above-mentioned regulation of the Government of SR, the category of invasive woody plants includes Acer negundo, Ailanthus altissima, Amorpha fruticosa, and Lycium barbarum. Black locust (Robinia pseudoacacia) was removed from the list of invasive plants. On the other hand, Medveckí et al. (2012) assessed Robinia pseudoacacia as an invasive woody species.

Research and permanent monitoring in each country needs to be focused towards reducing, controlling or possibly stopping the main invasive woody plant species in the landscape.

\section{Acknowledgements}

This study was elaborated thanks to the support by the project VEGA 1/0044/17, and projects KEGA 011SPU4/2019, KEGA 024SPU-4/2019, KEGA 046SPU-4/2018 and KEGA 003SPU-4/2020. The authors express their gratitude to Dr. Eva Strapáková for statistical processing of the results.

\section{References}

AlKuRDI, M.I.S., SupuKa, J., 2016. Study of mediterranean woody plants for hardiness in central Europe conditions. Prague: Powerprint s. r. o. 94 p.

BENČAŤ, F., 1982. Atlas rozširenia cudzokrajných drevín na Slovensku a rajonizácia ich pestovania. [Atlas of the distribution of exotic woody plants in Slovakia and zoning of their cultivation]. Bratislava: Veda. 359 p. + Annex $305 \mathrm{p}$.

BENČĂ̌, T., 1989. Black locust biomass production in Southern Slovakia. Acta dendrobiologica. Bratislava: Veda. 192 p.

Brundu, G., Richardson, D.M., 2016. Planted forests and invasive trees in Europe: a code for managing existing and future plantings to mitigate the risk of negative impact from invasion. NeoBiota, 30: 5-47. https://doi. org/10.3897/neobiota.30.7015 (23 June 2016)

BurdA, R., 2018. Alien plant species in the agricultural habitats of Ukraine: diversity and risk assessment. Ekológia (Bratislava), 37 (1): 24-31. https://doi.org/10.2478/eko2018-0003

Burda, R.I., Golivets, M.A., Petrovych, O.Z., 2015. Alien species in flora of the Nature Reserve Fund of the flatland part of Ukraine. Russian Journal of Biological Invasions, 6 (1): 6-20. doi: 10.1134/S2075111715010038

Colautti, R., MaC IsaAC, H., 2004. A natural terminology to define 'invasive species'. Diversity and Distribu- 
tions, 10: 135-141. https://doi.org/10.1111/j.1366.9516. 2004.00061.x

DANIŠ, D., 2008. Enumeration of allochtonous woody species impact risk rate on landscape elements. Acta Facultatis Ecologiae, 18: 13-19.

DemKovÁ, K., LiPSKÝ, Z., 2012. Rozptýlená zeleň v krajine Novodvorska a Žehušicka [Dispersed vegetation in the landscape of Nové Dvory and Žehušice region]. Acta Průhoniciana, 101: 51-59.

Drake, J.A., Mooney, H.A., Dicastri, F., Groves, R.H., Kruger, F.J., Rejmánek, M., Williamson, M., 1989. Biological invasions: a global perspective. SCOPE 37. New York, Toronto, Singapore: John Wiley and Sons. 252 p.

ELıÁšs, P., 1997. Biologické invázie ako celosvetový problem [Biological invasions as a global problem]. In Eliáš, P. (ed.). Invázie a invázne organizmy. Príspevky $z$ vedeckej konferencie. Nitra, 19. novembra 1996. Bratislava: Slovenský národný komitét Scope, p. 9-28.

Finch, S., BALDwin, S. (eds), 1991. Windbreaks and agroforestry. The third international symposium proceedings. Ridgetown, Canada: Ridgetown College. 266 p.

Hammer, Ø., 2015. PAST. Reference manual. Oslo: Natural History Museum, University of Oslo. 186 p.

HEAD, L., 2017. The social dimensions of invasive plants. Nature Plants, 3 (6): 1-7. https://doi.org/10.1038/ nplants.2017.75

Heisler, G.M., Dewalla, R.D., 1988. Effects of windbreak structure on wind flow. Agriculture, Ecosystems and Environment, 22/23: 41-69. https://doi.org/10.1016/01678809(88)90007-2

Henderson, I., 1998. Invasive alien woody plants of the southern and southwestern Cape region. South Africa. Bothalia, 28 (1): 91-112.

HodGe, S., 1995. Creating and managing of woodlands around towns. Forestry Commission handbook, 11. London: HMSO. $176 \mathrm{p}$.

HoŤKa, P., BARTA, M., 2012. Dreviny Arboréta Mlyňany SAV [Inventory of living collections of the Mlyňany Arborétum SAS]. Bratislava: Veda. $132 \mathrm{p}$.

JuRKo, A., 1990. Ekologické a socioekonomické hodnotenie vegetácie [Ecological and socio-economical evaluation of vegetation]. Bratislava: Príroda. 200 p.

Kaločaiová, M., 2005. Invázne dreviny vo vybranej časti mesta Nitra [Invasive woody plants in chosen parts of the Nitra town]. Nitra: Univerzita Konštantína Filozofa. 80 p.

KeLbel, P., 2005. The biotic pests of invasive and expansive woody plants in the Botanical garden of P.J. Šafárik University in Košice. Thaiszia - Journal of Botany, 15, Suppl.1: 197-210.

KelBel, P., 2012. Comparison of invasive woody plant species presence in the Botanical garden of P. J. Šafárik University in Košice from the viewpoint of time and management of sanitation measures. Thaiszia - Journal of Botany, 22 (2): 163-180.

Korda, M., 2015. A brief overview of technologies used for controlling invasive alien plant species. In CsIszár, A., Korda, M. (eds). Practical experiences in invasive alien plant control. Rosalia Handbook. Budapest: Duna-Ipoly National Park Directorate, p. 37-44.
KrajČovičová, D., ŠAJBidorová, V., 2014. The adaptive ability of Cornus stolonifera Michx 'Kelseyi' in changing environment. Acta Horticulture et Regiotecturae, 15 (1): 20-23. https://doi.org/10.2478/ahr-2014-0006.

KuBA, J., TомаŠKo, I., 2005. Introduction and invasion of dendrotaxa in Arboretum Mlyňany SAS. Thaiszia - Journal of Botany, 15, Suppl. 1: 211-214.

Lambdon, P.W., Pyšek, P., Basnu, C., Hejda, M., Arianoutsou, M., Essl, F., Jarošík,V., Pergl, J., Winter, M., Anastasiu, P., Andriopoulos, P., Bazos, I., Brungu, G., Celesti-Grapow, L., Chassot, P., Delipetrous, P., Josepsson, I., Kark, S., Klotz,S., Kokkoris, J., Kuhn,I., Marchante, H., Pergelová, I., Pino, J., Vila, M., Zikos, A., Roy, D., Hulme, P.E., 2008. Alien flora of Europe: species diversity, temporal trends, geographical patterns and research needs. Preslia, 80: 101-149.

MaglockÝ, Š., 2002. Potenciálna prirodzená vegetácia 1: 500000 [Potential natural vegetation]. In Atlas krajiny Slovenskej Republiky 1: 500 000. Bratislava: Ministerstvo životného prostredia; Banská Bystrica: Slovenská agentúra životného prostredia, 2002, p. 114-115.

Medvecká, J., Kliment, J., Máseková, J., Halada, L., ZALiberová, M., GoJdičová, E., Feráková, V., JarolímeK, I., 2012. Inventory of alien flora of Slovakia. Preslia, 84: 257-309.

ModRANSKÝ, J., DANIš, D., 2006. Invázne a expanzné introdukované dreviny v podmienkach Slovenska [Invasive and expansive introduced woody species on conditions of Slovakia]. In MŇAHONČÁKová, E., BARuszová, M. (eds). In Sídlo - park - krajina IV. Kultúrna vegetácia v sídlach a v krajine. Nitra: Slovenská pol’nohospodárska unvierzita, p. 211-219.

Moravec, J. a kol., 1994. Fytocenologie [Phytocenology]. Praha: Academia. 404 p.

Pyšek, P., Danihelka, J., SÁdlo, J., Chrtek, J.JR., Chytrý, M., Jarošík, V., Kaplan, Z., Krahulec, F., Moravcová, L., Pergl, J., Štajerová, K., TichÝ, L., 2012. Catalogue of alien plants of the Czech Republic (2nd edition): checklist update, taxonomic diversity and invasion patterns. Preslia, 84: 155-255.

Pyšek, P., SÁdlo, J., MANdÁK, B., 2002. Catalogue of alien plants of the Czech Republic. Preslia, 74: 97-186.

Richardson, D.M., Pyšek, P., Rejmanek, M., Barbour, M.G., Panetta, D.F., West, C.J., 2000. Naturalisation and invasion of alien plants: concepts and definitons. Diversity and Distributions, 6 (2): 93-107. https://doi. org/10.1046/j.1472-4642.2000.00083.x

SALAš, P., LuŽNÝ, J., 2010. Stručná historie zahradnictví IV [Short history of horticulture IV]. Brno: Mendelova univerzita v Brně, Zahradnícka fakulta. $112 \mathrm{p}$.

SOLTNER, D., 1991. L'arbre et la haie [Trees and hedges]. Angers: Collection Sciences et Techniques Agricoles. 203 p.

SupuKA, J., 1996. The importance of arboreta and botanical gardens in Slovakia for introduction, gene pool conservation and utilisation of plants. Biuletyn Ogrodow Botanicznych, Muzeow i Zbiorow, 5: 13-18.

SuPUKA, J., 1997. Invázne versus naturalizované dreviny v urbanizovanom prostredí [Invasive versus naturalised woody plants in urbanized environment]. In ELIáš, P. (ed). Invázie a invázne organizmy. Príspevky z vedeckej 
konferencie. Nitra, 19. novembra 1996. Bratislava: Slovenský národný komitét Scope, p. 182-189.

SuPUKA, J., ŠInKA, K., 2018. Land use changes and development of the non-forest woody vegetation in the Danubian Lowland in Slovakia. Central European Forestry Journal, 64: 3-15. doi: 10.1515/forj-2017-0029

Supuka, J., Šinka, K., Pucherová, Z., Verešová, M., FerIANCová, L., BihuŇová, M., KuczMan, G., 2013. Landscape structure and biodiversity of woody plants in the agricultural landscape. Folia Universitatis Agriculturae et Silviculturae Mendelianae Brunensis, Monographic series, vol. VI, no. 9. Brno: Mendel University in Brno. $187 \mathrm{p}$.

ŠPulerová, J., DobrovodSkÁ, M., Šatalová, B., KanKa, R., 2017. Small woodlands and trees in traditional agriculture landscape of Slovakia. Journal of Landscape Ecology, 10: $1-15$.

ThÉBaud, C., Debussche, M., 1991. Rapid invasion of Fraxinus ornus L. along the Hérault River system in Southern France: the importance of seed dispersal by water. Journal of Biogeography, 18: 7-12.

Tóth, A., Kuczman, G., Feriancová, L., 2016. Species composition and diversity of non-forest woody vegetation along roads in the agricultural landscapes. Lesnicky časopis - Forestry Journal, 62 (1): 57-66.
Uhrin, P., SupuKa, J., BiLliková, M., 2018. Growth adaptability of Norway maple (Acer platanoides L.) to urban environment. Folia Oecologica, 45 (1): 33-45. https:// doi.org/10.2478/foecol-2018-0004.

VEREŠOvÁ, M., SuPUKA, J., 2012. Kultúrno-historické a vizuálno-estetické hodnoty vinohradnickej krajiny [Cultural, historical and visual aesthetic values of the vineyard landscape]. Nitra: Slovenská pol'nohospodárska univerzita. $112 \mathrm{p}$.

Warren, C., 2007. Perspectives on the 'alien' versus native species debate: a critique of concepts, language and practice. Progress in Human Geography, 31 (4): 427-446. https://doi.org/10.1177/0309132507079499

White, R.J., Carreiro, M.M., ZipPerer, W.C., 2014. Woody plant communities along urban, suburban, and rural streams in Louisville, Kentucky, USA. Urban Ecosystem, 17: 1061-1094. doi: 10.1007/s11252-014-0376-x.

ZACHAR, D., TeŠLIAR, J., 1989. História vetrolamov na Slovensku [History on windbreaks in Slovakia]. In Polyfunkčná zeleň v pol’nohospodárskej krajine. Bratislava: Veda, p. 20-27. https://www.enviro.gov.sk

Received April 15, 2020 Accepted August 31, 2020 